\title{
An Immunocytochemical Study of Human Pituitary Mammotropes from Fetal Life to Old Age ${ }^{1}$
}

\author{
BURTON L. BAKER AND YA-YEN YU 2 \\ Department of Anatomy and Reproductive Endocrinology Program, \\ The University of Michigan Medical School, \\ Ann Arbor, Michigan 48109
}

\begin{abstract}
The objectives were to (a) describe the cytology and distribution of mammotropes in the human pituitary gland, (b) determine whether the mammotrope is a distinctive secretory cell type and (c) ascertain when it first appears in the fetal hypophysis. Identification of mammotropes was based primarily on the Sternberger peroxidase-antiperoxidase immunocy tochemical method used with an antiserum to human prolactin. Hypophyses from 25 male and 6 female adults, and 21 fetuses ranging in gestational age from 6 to 23 weeks were studied.

In the adult two morphological forms of mammotropes were observed. Mammotrope I possessed a small perikaryon that commonly was located centrally in parenchymal cell cords. From the perikaryon long cytoplasmic processes extended toward neighboring capillaries. Mammotrope I reached its highest incidence in the posterolateral zones of the pars distalis. Mammotrope II possessed a larger perikaryon with short processes; cells of this form were fewer and occurred chiefly in the anteromedian zone. Mammotropes with in termediate morphological features that prevented classification into categories I or II were common in some hypophyses.

Both forms of mammotropes were present prepuberally (one 6-week and one 9 -year-old male) and in adult males and females. Mammotropes were only slightly more prominent in females than males. Regression of mammotropes was evident in old age. Mammotropes were distinctly different from soma to tropes, corticotropes, gonadotropes and thyrotropes. In the fetal hypophysis mammotropes appeared first at 14 weeks of gestational age and remained few through 16.5 weeks. Their number increased greatly at 23 weeks.
\end{abstract}

Since 1969 it has become clear that the human hypophysis secretes prolactin. This hormone is now available in purified form (Lewis et al., '71; Chrambach et al., '71; Hwang et al., '72; Ben-David et al., '73) and seems to be distinct from other pituitary hormones. Although human prolactin and growth hormone are of similar molecular size, they differ immunologically (Friesen et al., '70; Guyda et al., '71; Bryant et al., '71; Friesen et al., '72; Hwang et al., '71), biologically (Frantz and Kleinberg, '70) and electrophoretically (Lewis et al., '71). This information, and availability of the purified hormone, make critical cytological study of the prolactin cell (mammotrope) possible in man.

In earlier investigations histological ${ }^{3}$ staining was used to reveal cells that were believed to be mammotropes because of their prominence in situations associated with accelerated secretion of prolactin.
With the tetrachrome staining procedure Pasteels (63) and Herlant and Pasteels ('67) observed many ery throsinophils (mammotropes) in the maternal hypophysis from the seventh month of pregnancy to full term, but these cells were hardly detectable in adult males and nonpregnant females. Using Brookes' ('68) stain, Goluboff and Ezrin ('69) observed many carmoisinophilic cells in the maternal hypophysis only during pregnancy and lactation and proposed that they secrete prolactin.

More recently, immunological labeling

\footnotetext{
Accepted Oct. 6, '76.

1 Supported in part by a Research Grant HD-03159 from the National Institute for Child Heal th and Human Development.

2 We thank Frances Wicks and Rosalie Proulx for their technical assistance.

3 The term "immunohistological" is used to encompass both immunofluorescence and immunocytochemical methods. "Hi stological" as applied to stain ing procedures includes those that depend on primary chemical and/or physical interaction between adye and the tissue section.
} 
techniques have been employed for identification of mammotropes in the human hypophysis. Utilizing an immunofluorescence procedure with anti-ovine prolactin, Pasteels et al. ( $72 \mathrm{abc}$ ) reported that mammotropes (a) include the erythrosinophilic cells, (b) are present in all adult human hypophyses studied, (c) hypertrophy during gestation, beginning at the third month, and (d) increase in number and size in fetal hypophyses from the sixteenth week to term. Zimmerman et al. (74) used immunocytochemistry with anti-ovine prolactin ${ }^{4}$ to identify mammotropes. More recently Halmi et al. (75) accomplished the same result with anti-rat prolactin. In summary, these studies demonstrated that mammotropes are present in hypophyses of both sexes and that immunohistological ${ }^{5}$ methods reveal many more mammotropes than are demonstrable with histological staining.

Several aspects of human mammotrope cytology require additional exploration because available relevant information is insufficient or conflicting. These problems include (a) determination of the distribution of mammotropes in the pituitary gland, (b) differentiation of mammotropes from other parenchymal cell types, particularly the somatotropes, and (c) assessment of the time when mammotropes first appear in the fetal hypophysis. Our study addresses these issues and, in contrast to previous immunohistological studies in which antisera to ovine or rat prolactin were used, is based primarily on utilization of an antiserum to human prolactin. It is the first study that uses differentiation of the mammotrope from other cell types as a means of supporting the specificity of the immunocytochemical procedures.

\section{MATERIALS AND METHODS}

\section{Adult hypophyses}

Hypophyses from adults were obtained at autopsy in the University of Michigan Hospital. The cases included 6 females ranging in age from 26 to 72 years and 26 males with ages ranging from 6 weeks to 89 years. Major endocrinopathies were not evident in any of the cases. Many of the individuals had been killed by violent means and in them long-standing pathological changes were often minimal. Greatest reliance was placed on 18 specimens from cases in which autopsy was performed within three to eight hours after death. These included all six glands from females. The other specimens obtained after longer postmortem intervals were used for reference; in spite of the elapse of many hours between death and fixation the various secretory cell types could often be demonstrated with remarkable clarity by means of immunocytochemistry.

Each hypophysis was divided horizontally into a superior and an inferior half or was cut sagitally into three segments, the median one including the infundibular stem. Fixation in Bouin's fluid continued for 48 hours, after which the tissue was dehydrated and embedded in Paraplast. In order to facilitate study of the distribution of mammotropes, careful orientation of the pieces of each hypophysis was maintained during embedding and serial sectioning at 3-5 $\mu \mathrm{m}$. Every fortieth section was mounted and stained with Harris' hematoxylin and the Masson (28) procedure. Observation of these preparations enabled one to select sections for subsequent immunocytochemical labeling that represented desired levels in the gland. Usually sections from three levels in each glandular segment were labeled for prolactin, thus making possible evaluation of the cells in as many as nine different levels of the gland.

In order to correlate the mammotropes revealed immunocytochemically with the cells considered to be mammotropes by earlier investigators who employed histological staining methods, some sections were stained with the Brookes' ('68) carmoisine L-wool green S-orange G procedure. Comparison of individual cells was made possible by staining the middle one of three consecutive sections with a histological method and labeling the other two immunocytochemically for prolactin and one other pituitary hormone.

\section{Immunocytochemistry}

Sections were labeled immunocytochem-

4The prefix "anti-" indicates an antiserum to the hormone subsequently named. The following abbreviations are used for the hormonal antigens: Prl, prolactin (mammotropin); GH, growth hormone (somatotropin); CG, chorionic gonadotropin; PL, placental lactogen; TSH, thyrotropin; and ACTH, corticotropin. When the name of the hormone is abbreviated, a preceding small letter indicates the species of origin for the hormonal antigen, e.g., h, human; $m$, monkey; o, ovine; r, rat; b, bovine.

5 See footnote 3 page 217. 
TABLE 1

Summary of antisera used in this study

\begin{tabular}{|c|c|c|c|}
\hline Antiserum & Source & $\begin{array}{l}\text { Dilution for } \\
\text { labeling }\end{array}$ & Immunogens \\
\hline Anti-h Prl & Calbiochem 1 & $1 / 25$ & \\
\hline Anti-rPrl 2 & A. F. Parlow & $1 / 600$ & \\
\hline Anti-rPrl(625) 2 & A. R. Midgley & $1 / 150$ & \\
\hline Anti-oPrl(B107) & BLB & $1 / 100$ & NIH-P·S6 \\
\hline Anti-h GH(B85) ${ }^{2}$ & BLB & $1 / 200$ & NIH-GH-HS1395 \\
\hline Anti-h CG(391) 2 & A. R. Midgley & $1 / 2,000$ & \\
\hline Anti-h TSH $\beta^{3}$ & J. G. Pierce & $1 / 3,000$ & \\
\hline \multirow{4}{*}{$\begin{array}{l}\text { Anti-p } \beta^{17-39}-\mathrm{ACTH} \\
(\mathrm{B} 39) \\
\text { Anti- } \beta^{1-24}-\mathrm{ACTH} \\
(\mathrm{B} 44)\end{array}$} & & & \multirow{4}{*}{$\begin{array}{l}\text { Synthetic cortico- } \\
\text { tropins, Ciba-Geigy, } \\
\text { Basel }\end{array}$} \\
\hline & BLB & $1 / 25$ & \\
\hline & & & \\
\hline & BLB & $1 / 100)$ & \\
\hline
\end{tabular}

19933 N. Torrey Pines Road, LaJolla, California 92037.

2 Absorbed with human liver powder and charcoal.

3 Absorbed with hCG.

ically by the method of Sternberger et al. (70) as modified by Petrali et al. (74) for electron microscopy. We have found that this procedure, with only minor alterations, is useful for light microscopy. In general, the anti-Prl and the sheep antiserum to rabbit $\gamma$-globulin were applied for 30 minutes at room temperature. Incubation in 3,3'diaminobenzidene $(\mathrm{DAB})$ was at $5^{\circ} \mathrm{C}$ and the time varied from 5 to 30 minutes.

The antisera employed in this study, including anti-hPrl, are listed (table 1) together with their sources and the dilutions utilized for immunocytochemistry. The antihPrl was weak and could not be diluted beyond 1/25 if maximal labeling was to be obtained with the Sternberger procedure. At a dilution of 1/50 the antiserum was ineffective. The prolactin antigen used for preparation of anti-hPrl by Calbiochem was purified by the method of Friesen and collaborators (Friesen et al., '70; Hwang et al., '72). According to the supplier, contamination with LH, FSH, TSH, and growth hormone was less than $1 \%$. In addition two antisera (table 1) to rat prolactin (No. 625 and one supplied by Doctor A. F. Parlow) as well as one to ovine prolactin (B107) were utilized in order to compare their labeling properties with that of anti-hPrl. The anti-o Prl (B107) was prepared in this laboratory according to the immunization procedure of Midgley et al. ('71). Since Halmi et al. (75) found that anti-rPrl must be applied to human hypophyses for four days in order to label mammotropes immunocytochemically, we explored the efficacy of prolonged application of the antiserum with anti-rPrl, anti-oPrl and anti-hPrl and also compared the results obtained with the three antisera.

In order to show that the human mammotropes were different from other secretory cell types it was necessary to label the latter cells immunocytochemically. Antisera for this purpose were obtained from the sources indicated (table 1). When used for radioimmunoassay or imm unocy tochemistry of the rat hypophysis, references concerned with specificity of these antisera are: anti-rPrl (No. 625), Baker et al. ('69); anti-hCG (No. 391), Midgley and Jaffe (71); anti-bTSH $\beta$, Pierce et al. (71), Baker, Pierce and Cornell ('72); anti$\mathrm{p} \beta^{17-39}$ and anti- $\beta^{1-24}$-corticotropin, Baker and Drummond ('72), Baker et al. (70); and anti-hTSH $\beta$, Phifer and Spicer ('73); Phifer et al. ('73). Other hormones used for absorption of the antisera were the following: NIH-hGH, hPrl (NIH-HPr-VLS3), NIH-hPL, $\beta^{1-24}$-corticotropin; $\quad \mathrm{p} \beta^{17-39}$ corticotropin; hCG (Lot No. 102C-0360), Sigma Chemical Co.; and hTSH (Lot 420018), Calbiochem. ${ }^{6}$

\section{Control and specificity of the immunocytochemical procedure}

Substitution of normal rabbit serum for anti-phPrl eliminated labeling of mammo-

\footnotetext{
6 We thank the NIAMDD National Pituitary Hormone Distribution Program for hPrl, hPL, and hGH; Dr. R W. Rittel, Ciba-Geigy, Basel, for syn thetic corticotropic peptides; and the NIAMDD Rat Pituitary Hormone Distribution Program (Dr. A. F. Parlow), Dr. A. R. Midgley, Jr. and Dr. J. G. Pierce for other antisera (table 1 ).
} 
tropes. Several steps were taken to acquire evidence regarding specificity of the anti-hPrl for immunocytochemical demonstration of mammotropes. First, anti-hPrl was absorbed with hPrl and other pituitary hormones prior to performance of the immunocytochemical procedure. For these absorptions, solutions of the absorbants were mixed $1: 1$ by volume with a $1 / 25$ dilution of anti-hPrl and incubated overnight. Subsequently, the effect of the absorption on the utility of anti-Prl for immunocytochemical labeling of mammotropes was observed. Labeling of mammotropes was eliminated completely after absorption with $\mathrm{hPrl}$ at a concentration of $0.5 \mathrm{mg} / \mathrm{ml}$; at concentrations as low as $5 \mu \mathrm{g} / \mathrm{ml}$ the intensity of labeling was reduced greatly but was not eliminated completely. On the other hand, at concentrations of $5 \mathrm{mg} / \mathrm{ml}, \mathrm{hGH}$, $\mathrm{hPl}, \mathrm{hCG}$ and $\beta^{1-24}$-corticotropin failed to neutralize anti-hPrl. hTSH at a concentration of $0.5 \mathrm{mg} / \mathrm{ml}$ did not neutralize antihPrl.

Loss in effectiveness of anti-hPrl after absorption with hPrl at low concentration, in contrast to retention of effectiveness of anti-hPrl after absorption with other pituitary hormones at higher concentration, is a strong indication that anti-hPrl is specific for demonstration of prolactin. Failure of other pituitary hormones to neutralize anti$h P r l$ suggests that anti-hPrl does not crossreact significantly with them. Similarly, Hwang et al. ('71) and Friesen et al. (72) observed in their radioimmunoassay for hPrl using anti-hPrl that the antiserum did not cross-react with the closely related hormones hGH, hPL and mPL. Further, Aubert et al. ("75) found that human fetal and adult prolactins do not differ in their immunochemical properties.

With respect to use of antisera to heterologous prolactins for demonstration of mammotropes in man, the specificity of anti-rPrl (No. 625) and of the anti-rPrl supplied by Doctor A. F. Parlow is indicated by elimination of immunocytochemical labeling following prior absorption of the antisera with hPrl at a concentration of $0.5 \mathrm{mg} / \mathrm{ml}$. The specificity of anti-r Prl No. 625 for use on the rat hypophysis was supported previously (Baker et al., '69) and the anti-rPrl supplied by Doctor A. F. Parlow permitted labeling of the same cells in rats as antiserum No. 625. Anti-oPrl
(B107) also was made ineffective for labeling of human mammotropes by preabsorption with $h$ Prl.

As an indirect indication of specificity several plans were followed to ascertain whether or not the mammotrope revealed immunocytochemically was different from the other secretory cell types. In a series of three consecutive sections, the middle one was labeled for prolactin, and the section on either side was labeled for one of the other pituitary hormones. Individual cells were compared in these sections to determine whether anti-hPrl delineated cells different from those revealed by antisera to the other pituitary hormones. Also, the double-immunocytochemical labeling procedure of Nakane and Pierce ('67) was adapted for use with the SternbergerPetrali PAP method and applied to human pituitary sections. In this procedure, $\mathrm{DAB}$ was used as electron donor for hPrl and 4-Cl-1-naphthol as marker for a second pituitary hormone. DAB imparts a gold color to the cell and the chlorinated naphthol a blue-gray color. Validity of the method depends on complete removal of all antibody from the section following the first labeling procedure. Attainment of this goal was demonstrated repeatedly by absence of labeling in a section incubated in the DAB substrate after application of rabbit antiserum to a hormone, and sheep anti-rabbit IgG, followed by $\mathrm{HCl}$ hydrolysis.

\section{Fetal hypophyses}

Twenty-one human fetuses were studied; details regarding their procurement, age and the technical methods used in preparing the hypophyses have been reported (Baker and Jaffe, '75). The specimens ranged in fertilization age from 6 to 23 weeks. The fetal hypophyses, with some adjacent tissue remaining attached, were fixed in Bouin's fluid for 24 hours. After embedding in paraffin, they were sectioned at $3 \mu \mathrm{m}$ in either a transverse or sagittal plane. Sections from several parts of the gland were labeled immunocytochemically for prolactin by the procedures described for the adult hypophyses.

\section{RESULTS}

The adult hypophysis

Postnatally the form of mammotropes varied greatly. Cells representing the ex- 


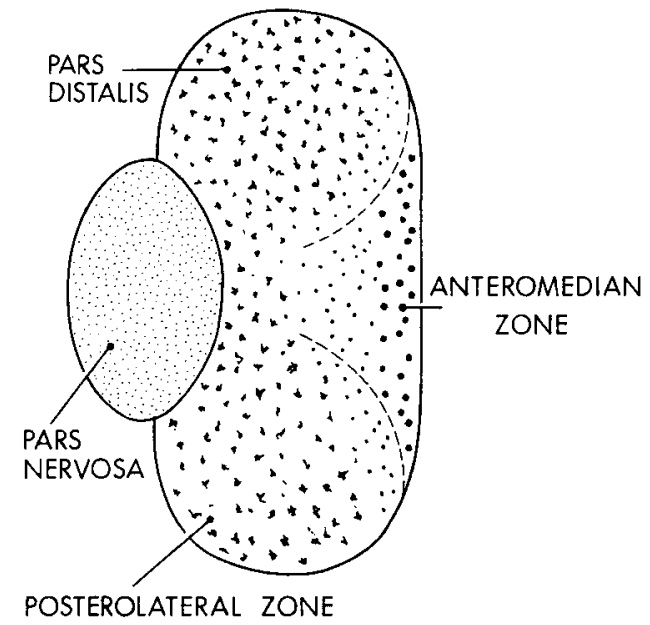

Fig. 1 A diagram of a transverse section of the hypophysis to show the distribution of mammotropes I and II. Mammotropes I, represented by indexes of irregular shape, are most common in the posterolateral and posteromedial zones. Mammotropes II (large solid circles) occur chiefly near the surface in the anteromedian zone. Transitional forms between mammotropes I and II (small solid circles) are common in the region intervening between the median and lateral zones.

tremes of this variation will be designated mammotrope I and II. Mammotrope I was stellate. Its small perikaryon (fig. 18) tended to be located in or near the center of parenchymal cell clusters (figs. 2, 4), although this arrangement was by no means constant. From the cell body, long cytoplasmic processes extended peripherally between neighboring cells to terminate in bulbous enlargements on the pericapillary space (fig. 18), thus giving the cell a spiderlike configuration. The cytoplasm of these processes was granulated but one could not certain whether this feature was due to deposits of oxidized $\mathrm{DAB}$ or reflected the presence of true secretory granules. Mammotropes I occurred singly (fig. 18) or in clusters (fig. 2) within parenchymal cell groups. They represented by far the greater proportion of mammotropes in the pars distalis. They were most common in the posterolateral wings of the pars distalis in association with the typically high concentration of somatotropes present there (figs. 1, 2, 4, 6). They also formed a bridge between the posterolateral zones across the median region just anterior to the pars nervosa. From these highly populated zones mammotropes I extended anteriorly, singly and as groups, into the more anterior regions of the gland. When considered on a cephalocaudal axis, the highest concentration of mammotropes I occurred at the middle and inferior levels of the pars distalis and the fewest mammotropes were present in the most cephalic (superior) portions of the lateral wings.

The mammotropes II differed from mammotropes I in size, form and distribution. This cell had a larger spherical or poly. hedral perikaryon with short or no cytoplasmic processes (figs. 3,5) and was restricted to the anteromedian zone ("Mucoid wedge" or "zona tuberalis" of other authors) especially at superior levels in the gland. More inferiorly the group of mammotropes II spread laterally, forming two bilateral columns near the anterior face of the gland. The incidence of mammatropes II was far less than that for mammotropes I, particularly in males.

Occurrence of the two forms of mammotropes was especially impressive in hypophyses from males. They were observed in one 6-week-old male (figs. 2, 3), one 9-yearold male (figs. 4,5 ) and in most mature males, thus demonstrating the presence of these cellular forms over a wide age range. In prepuberal males (figs. 2,4 ) they were about as numerous and as large as in mature males (fig. 6). Similarly, both forms of mammotropes occurred in the hypophyses from all three of the mature females who were in their active reproductive period (26-36 years of age), but a longer series would have been desirable to establish their incidence. In mature males and nonpregnant females the number of mammotropes seemed to be quite similar, with those of females being somewhat larger (fig. 7). In accord with the somewhat greater size of mammotrope perikarya in the posterolateral zones in females, the morphological contrast between mammotropes I and II became less distinct. Furthermore, in transitional areas between the posterolateral and anteromedian zones, mammotropes 1 generally exhibited a tendency to be more spherical.

The only case in which there was significant increase in size (figs. 19-21), and probably in number, occurred in a 26 . year-old female whose pregnant state was confirmed at autopsy. No data were available to permit accurate determination of 
the time in pregnancy; it was probably in the first trimester.

Mammotropes regressed with advancing age as manifested by a reduction in size and relative number. In three of four males 65 years of age and older, and in three females 48 to 76 years old, the mammotropes were exceptionally small and sparse (fig. 8) as compared with those of younger individuals.

In males and nonpregnant females it was not possible to stain mammotropes consistently with the Brookes'staining procedure, confirming the experience of Goluboff and Ezrin ('69) and of Halmi et al. (75) with this technique, and that of Pasteels et al. (72a) with erythrosine staining. Only a few mammotropes II stained occasionally with carmoisine-L. Thus, in histologically stained preparations mammotropes would generally be classed as chromophobes, and immunohistological procedures are required for their demonstration. However, in the one case of pregnancy, mammotropes I (fig. 24) and II (fig. 22) stained regularly and brilliantly with carmoisine-L. By matching consecutive sections, the second of which was labeled immunocytochemically for prolactin, the identity of carmoisinophils with mammotropes I (figs. 24, 25) and II (figs. 22, 23) was demonstrated readily.

Mammotropes were distinctly different from the other commonly recognized cell types. Most important is the relationship between the mammotropes and somatotropes. In contrast to the spider-like form and central location of mammotropes $I$ in cell cords (fig. 6), somatotropes were of more uniform ovoid to polyhedral shape, and tended to be located peripherally in cell cords (fig. 9). Also, by comparison of adjacent sections (figs. 16, 17) labeled individually for prolactin and growth hormone, different cells were revealed. In the anteromedian zone, mammotropes II and somatotropes were shown to be different cell types by double immunocytochemical labeling in a single section (fig. 14), one appearing gold and the other blue.

With respect to other cell types, mammotropes I differed greatly in cell form from the larger and usually ovoid corticotropes $(\beta[R]$ basophil) (fig. 15). The latter cells were generally located peripherally in cell cords, in contrast to the central position of mammotropes I. Also, in the posterolateral zone, the few but large polyhedral thyrotropes were peripheral in position and contrasted sharply in morphology with mammotropes I (fig. 13). In or near the anteromedian zone, the uniqueness of each cell type was impressively evident by comparison of adjacent sections, each labeled for either thyrotropin or prolactin (figs. 10,11). In the posterolateral zone the small, ovoid gonadotropes also were often located at the periphery of cell cords and differed considerably in shape from mammotropes I. In the anteromedian zone their generally smaller size, as compared with mammotropes II, was distinctive (fig. 12). Histological differences between the cell types as observed in this study are summarized (table 2).

\section{Interspecies applicability of antisera for immunocytochemical labeling}

By comparison of cells in neighboring sections labeled with anti-rPrl and anti$\mathrm{h} P \mathrm{Pr}$ and anti-oPrl, respectively, it was determined that the same cells were revealed in each instance (figs. 19-21). In contrast to the experience of Halmi et al. ('75), who reported that anti-rPrl must be applied to human pituitary sections for four days in order to achieve satisfactory labeling of mammotropes, we found a 30-minute application ample for each antiserum. One possible explanation for this difference in experience in the two laboratories might be that the time required for application of primary antiserum to the section is related inversely to dilution of the antiserum. However, this factor does not seem critical because we both obtained anti-rPrl from Doctor A. F. Parlow and we used a dilution of $1 / 600$ which was six times greater than that employed by Doctor Halmi.

\section{The fetal hypophysis}

Mammotropes were absent from hypophyses of specimens 6 to 13 weeks of fertilization age. With respect to the pars distalis, they were found in four of five fetuses at 14 weeks (figs. 26, 26a). In three cases mammotropes were few, in one case only one or two cells being present in a single transverse section. The hypophysis of another 14-week specimen contained more numerous mammotropes, and they were most common in the anteromedian zone. In horizontal sections at this and later stages they were demonstrable at all levels of the pars distalis. From 15.5 to 16.5 
TABLE 2

Differential characteristics of secretory cell types in the human pars distalis

\begin{tabular}{|c|c|c|c|}
\hline & \multirow[b]{2}{*}{ Sh ape } & \multicolumn{2}{|c|}{ Most common location } \\
\hline & & $\begin{array}{l}\text { In pars } \\
\text { distalis }\end{array}$ & $\begin{array}{l}\text { In parenchymal } \\
\text { cell cord }\end{array}$ \\
\hline Mammotrope I & $\begin{array}{l}\text { Spider-like, } \\
\text { small peri- } \\
\text { karyon, long } \\
\text { processes }\end{array}$ & $\begin{array}{l}\text { Posteromedial, } \\
\text { posterolateral }\end{array}$ & Central \\
\hline Mammotrope II & $\begin{array}{l}\text { Polyhedral, } \\
\text { large peri- } \\
\text { karyon, short } \\
\text { processes }\end{array}$ & Anteromedian zone & Not distinctive \\
\hline Som a totrope & $\begin{array}{l}\text { Ovoid to poly- } \\
\text { hedral, medium } \\
\text { size }\end{array}$ & $\begin{array}{l}\text { Posteromedial } \\
\text { posterolateral }\end{array}$ & Peripheral \\
\hline Corticotrope & Ovoid, large & $\begin{array}{l}\text { Anteromedian zone, } \\
\text { lateral wing }\end{array}$ & Peripheral \\
\hline Thyrotrope & $\begin{array}{l}\text { Ovoid to poly- } \\
\text { hedral, large }\end{array}$ & Anteromedian zone & Not distinctive \\
\hline Gonadotrope & Ovoid, small & $\begin{array}{l}\text { Anteromedian zone, } \\
\text { lateral wing }\end{array}$ & Peripheral \\
\hline
\end{tabular}

weeks mammotropes occurred in seven of eight specimens (figs. 27, 27a). In these glands the number of mammotropes was variable and they were scattered widely in the gland. In a single specimen of 23 weeks, mammotropes comprised a prominent proportion of the pars distalis cells (figs. 28, 28a) and had become generally distributed in the pars distalis, with the densest population occurring in the posterior half, especially in the lateral wing. At $\mathbf{1 6 . 5}$ and 23 weeks, the anteromedian zone contained fewer mammotropes than the posterolateral zones. Furthermore, differentiation into mammotropes I and II was clearly evident.

Mammotropes were absent from the pars intermedia in all fetuses. At 15.5 (fig. 27) and 16.5 weeks, mammotropes were demonstrable in the pars tuberalis, particularly where this lobe is associated with the median eminence. Mammotropes also appeared in the dorsolateral extensions of the adenohypophysis that encompassed the inferior portion of the infundibular stem at its junction with the pars nervosa. Atwell ('26) regarded these extensions as part of the pars intermedia but they may be a component of the pars tuberalis.

\section{DISCUSSION}

\section{Uniqueness of the mammotrope as a} secretory cell type

Assumption that the mammotrope, as demonstrated herein, is a distinctive secre- tory cell type is based chiefly on specificity of the immunocytochemical techniques for demonstration of prolactin. Although final proof of specificity must await studies with synthetic human prolactin, presently available evidence suggests that the antihPrl used in this study is specific. Particularly significant was loss in effectiveness of the antiserum after absorption with $h P r l$ and continued effectiveness of the antiserum after absorption with other pituitary hormones. Specificity is also suggested by the broad interspecies utility of antisera to prolactins for immunocytochemical labeling of mammotropes, as shown by successful delineation of these cells in the human hypophysis with antirPrl and anti-oPrl. This condition appears to exist because of homologies in the primary structures (Niall, '72; Parlow and Shome, '76) of the prolactins from these species that result in immunological crossreactivity (Aubert et al., '75). On the other hand, anti-hPrl was not effective in permitting immunocytochemical labeling of mammotropes in the rat. This is the only instance known to us in which an antiserum to a human hormone cannot be used with the rat. Similarly, although our antisera to ovine prolactin can be used for labeling of rat mammotropes, the result is less intense than that obtained with antisera to rat prolactin prepared in two different laboratories. It may be relevant that Ellis et al. ('69) found that anti- 
$r$ Prl does not react with oPrl in complement fixation studies.

Some debate may still exist concerning the individuality of the mammotrope as a secretory cell type. In consecutive sections immunocytochemically labeled for prolactin and growth hormone, Zimmerman et al. (74) observed that differential counts of mammotropes and somatotropes in some areas of the gland exceed $100 \%$, and they raised the possibility that prolactin and somatotropin may occur together in some cells. Our findings on consecutive sections similarly prepared, and in others doubly labeled for the two hormones, tend to eliminate this possibility because in neither case were similarities in structural or distributional characteristics of mammotopes and somatotropes observed.

The evidence presented that the mammotrope is distinctly different from the thyrotrope is especially significant since administration of thyrotropin-releasing hormone (TRH) to man induces pituitary secretion of both prolactin and thyrotropin (Daughaday and Jacobs, '72). This effect would be easily explained if both hormones were produced by the same cell but this seems not to be the case. Thus TRH must stimulate both thyrotropes and mammotropes directly or may effect prolactin secretion indirectly through alteration in release of regulatory hypothalamic factors.

\section{The significance of two cytological forms of mammotropes}

Although not now understood, the functional meaning for the existence of two morphological forms of mammotropes is intriguing. Since mammotrope $I$ is restricted mainly to the posterolateral areas of the gland where somatotropes form a dense population, its spider-like form might be merely a physical response to pressure exerted by the somatotropes. In the anteromedian zone most parenchymal cells tend more toward an ovoid form and such intercellular pressure may not exist. In spite of the evidence that tends to confirm the specificity of our procedure for localization of human prolactin, the possibility myst be entertained that mammotropes I and II possess different functional capacities. Future studies of their response to alteration in circulating levels of regulatory hormones should illuminate this issue.
The findings reported here revealed no impressive difference in the comparative incidences of the two forms between the sexes, or with respect to age in males.

\section{Correlation with previous descriptions of mammotropes}

Our observations bear on several aspects of mammotrope cytology that have been considered by previous investigators. Pasteels et al. (72a) noted the general atrophy of mammotropes that is evident in postmenopausal women and in old men. This conclusion was confirmed by our findings. Pasteels et al. (72c) reported moderate regression of mammotropes in children; our limited observations indicate that they may be almost as prominent as in adults. They also noted a paucity of mammotropes in some young men, which was not the case in our series. They further noted that most mammotropes are located near the gland periphery. In our study, the large mammotrope II and some mammotropes I were common to the peripheral anteromedian zone. However in terms of number, the population of mammotropes I present throughout the posterior zone of the pars distalis was certainly much greater.

\section{Correlation of mammotrope cytology with prolactin levels in the body}

The cytology of mammotropes is helpful in understanding several aspects of prolactin physiology in man. First, the small size of most mammotropes and their small relative number indicates that the prolactin content of the human hypophysis of males and nonpregnant females should be low. Also, failure of mammotropes to stain with histological procedures suggests that the amount of hormone stored per cell is exceedingly low. Radioimmunoassay of the human hypophysis has shown that it contains only 75-150 $\mu \mathrm{g}$ of prolactin (Friesen et al., '72; Daughaday and Jacobs, '72), as compared with 10-30 mg of growth hormone (Lloyd et al., '69). This condition is one of the reasons why the isolation and purification of human prolactin has been so difficult. Second, there seems to be little difference in the number of mammotropes between the sexes although size seems to be somewhat greater in females, suggesting that the amount of 
prolactin secreted in the sexes may be similar. This indication is supported by the radioimmunoassay data of Friesen et al. (72) and Jacobs et al. ('72) on concentration of prolactin in human serum. These investigators demonstrated that the range of values obtained in adult males and females overlap, with the mean being somewhat higher in females. Thus, Jacobs et al. reported a mean of $6.2 \pm 0.6 \mathrm{ng} / \mathrm{ml}$ for adult men and $9.0 \pm 0.6 \mathrm{ng} / \mathrm{ml}$ for adult nonpregnant women. Further, mammotropes in the two male children studied by us ( 6 weeks and 9 years of age) resembled those of adults; Daughaday and Jacobs (72) found the mean level of prolactin in sera of normal children to be similar to that of adults $(7.0 \pm 1.2 \mathrm{ng} / \mathrm{ml})$. Third, the greater abundance and hypertrophy of mammotropes that occurred in the maternal hypophysis of one pregnant woman confirms the previous reports of others who used histological staining (Goluboff and Ezrin, '69) and immunofluorescence (Pasteels et al., '72a). According to these authors the development of mammotropes intensified with progression of the third trimester; likewise the serum concentration of prolactin rises sharply between the ninetieth day of pregnancy and parturition (Friesen et al., '72).

\section{Genesis of mammotropes in the fetal hypophysis}

Although Pasteels et al. ('72a) reported the presence of mammotropes in the 16week human fetus and their absence at 14 weeks, we observed their fairly regular presence at 14 weeks. Recognizing the possibility of significant error in estimation of fertilization age from the crown-rump length, the observations from these two laboratories probably represent substantial agreement. From 14 weeks through 16.5 weeks the number of mammotropes in our specimens was usually small, thus accounting for the failure of Aubert et al. (75) to detect prolactin in the hypophyses of 12 of 23 human fetuses, 17 weeks or younger, with radioimmunoassay. However, they reported the presence of prolactin in some cases as early as 10 weeks, which is at least four weeks earlier than it has been found with immunocytochemistry. Even more out of line with immunohistological timing of prolactin appearance in the fetal hypophysis is the report by SilerKhodr et al. ("74) that immunoreactive prolactin activity occurs in the culture medium of human pituitaries as young as five weeks of gestational age; at this time significant cytological differentiation has not occurred in the pituitary anlage. In later pregnancy the large number of mammotropes present in our 23-week old specimen correlates well with the large increase in pituitary prolactin content and concentration that Aubert et al. (75) observed between 14 and 23 weeks.

\section{LITERATURE CITED}

Atwell, A. J. 1926 The development of the hypophysis cerebri in man, with special reference to the pars tuberalis. Amer. J. Anat., 37 : 159-192

Aubert, M. L., M. M. Grumbach and S. L. Kaplan 1975 The ontogenesis of human fetal hormones. III. Prolactin. J. Clin. Invest., 56: 155164.

Baker, B. L., and T. Drummond 1972 The cellular origins of corticotropin and melanotropin as revealed by immunochemical staining. Amer. J. Anat., $134: 395-409$.

Baker, B. L., and R. B. Jaffe 1975 The genesis of cell types in the adenohypophysis of the human fetus as observed with immunocytochemistry. Amer. J. Anat., 143: 137-160.

Baker, B. L., A. R. Midgley, Jr., B. E. Gersten and Y.-Y. Yu 1969 Differentiation of growth hormone- and prolactin-containing acidophils with peroxidase-labeled antibody. Anat. Rec., 164 . 163-171.

Baker, B. L., S. Pek, A. R. Midgley, Jr. and B. E. Gersten 1970 Identification of the cortico tropin cell in rat hypophyses with peroxidaselabeled antibody. Anat. Rec., 166:557-567.

Baker, B. L., J. G. Pierce and J. S. Cornell 1972 The utility of antiserums to subunits of TSH and LH for immunochemical staining of the rat hypophysis. Amer. J. Anat., 135: 251-267.

Ben-David, M., D. Rodbard, R. W. Bates, W. E. Brudson and A. Chrambach 1973 Human prolactin in plasma, amniotic fluid and pituitary: identity and characterization by criteria of electrophoresis and isoelectric focusing in polyacrylamide gel. J. Clin. Endocr. Metab., 36:951-964.

Brookes, L. D. 1968 A stain for differentiating two types of acidophils in the rat pituitary. Stain Tech., 43: 41-42.

Bryant, G. D., T. M. Siler, E. C. Greenwood, J. L Pasteels, C. Robyn and P. O. Hubinont 1971 Radioimmunoassay of a human pituitary prolactin in plasma. Hormones, 2 : 139-152.

Chrambach, A., W. E. Bridson and R. W. Turkington 1971 Human prolactin: identification and physical characterization of the biologically ac. tive hormone by polyacrylamide gel electrophoresis. Biochem. Biophys. Res. Commun., 43: 1296-1303.

Daughaday, W. H., and R. S. Jacobs 1972 Human prolactin. Ergebn. Physiol. Biol. Chem. Pharm., 67: 169-194. 
Ellis, S., R. E. Grindeland, J. M. Nuenke and P. $X$. Callahan 1969 Purification and properties of rat prolactin. Endocrinology, 85: 886-894.

Frantz, A. G., and D. L. Kleinberg 1970 Prolactin: evidence that it is separate from growth hormone in human blood. Science, 170: 745747.

Friesen, H., H. Guyda and J. Hardy 1970 Biosynthesis of human growth hormone and prolactin. J. Clin. Endocr. Metab., 31:611-624.

Friesen, H., P. Hwang, H. Guyda, G. Tolis, J. Tyson and R. Myers 1972 A radioimmunoassay for human prolactin. Physiological, pathological and pharmacological factors which affect the secretion of prolactin. In: Prolactin and Carcinogenesis. A. R. Boyns and K. Griffiths, eds. Proc. 4th Tenovus Workshop, Cardiff, Wales, pp. 64-80.

Goluboff, L. G., and C. Ezrin 1969 Effect of pregnancy on the somatotroph and the prolactin cell of the human adenohypophysis. J. Clin. Endocr. Metab., 29: 1533-1538.

Guyda, H., P. Hwang and H. Friesen 1971 Immunologic evidence for monkey and human prolactin (MPr and HPr). J. Clin. Endocr. Metab., $32: 120-123$.

Halmi, N. S., J. A. Parsons, S. L. Erlandsen and T. Duello 1975 Prolactin and growth hormone cells in the human hypophysis: a study with immunoenzyme histochemistry and differential staining. Cell Tiss. Res., 158:497-507.

Herlant, M., and J. R. Pasteels 1967 Histophysiology of human anterior pituitary. Meth. Achievm. Exp. Path., 3: 251-305.

Hwang, P., H. Guyda and H. Friesen 1971 A radioimmunoassay for human prolactin. Proc. Nat. Acad. Sci., (U.S.A.), 68: 1902-1906. 1972 Purification of human prolactin. J. Biol. Chem., 247: 1955-1958.

Jacobs, L. S., I. K. Mariz and W. H. Daughaday 1972 A mixed heterologous radioimmunoassay for human prolactin. J. Clin. Endocr. Metab., $34: 484-490$.

Lewis, U. J., R. N. P. Singh and B. K. Seavey 1971 Human prolactin: isolation and some properties. Biochem. Biophys. Res. Commun., 44: 1169-1176.

Lloyd, H. M., K. J. Donald, K. J. Catt and G. H Burger 1969 Growth hormone concentration in human pituitary tumors. J. Endocr., 45: 133-134

Masson, P. 1928 Carcinoids (argentaffin-cell tumors) and nerve hyperplasia of the appendicular mucosa. Amer. J. Path., 45: 181-212.

Midgley, A. R., Jr., and R. B. Jaffe 1971 Regulation of human gonadotropins: $\mathrm{X}$. Episodic fluctuation of $\mathrm{LH}$ during the menstrual cycle. J. Clin. Endocr. Metab., 33: 962-969.

Midgley, A. R., Jr., G. D. Niswender, V. L. Gay and L. E. Reichert, Jr. 1971 Use of antibodies for characterization of gonadotropins and steroids. Rec. Progr. Horm. Res., 27: 235-301.

Nakane, P. K., and G. B. Pierce, Jr. 1967 Enzyme-labeled antibodies for the light and elec tron microscopic localization of tissue antigens. J. Cell Biol., 33: 307-318.

Niall, H. D. 1972 The chemistry of the human lactogenic hormones. In: Prolactin and Carcinogenesis. A. R. Boyns and K. Griffiths, eds. Proc. 4th Tenovus Workshop, Cardiff, Wales, pp. 1320.

Parlow, A. F., and B. Shome 1976 Rat prolactin: the entire linear amino acid sequence. Fed. Proc., 35: 219

Pasteels, J. L. 1963 Recherches morphologiques et expérimentales sur la sécretion de prolactine. Arch. Biol. (Brussels), 74: 439-553.

Pasteels, J. L., P. Gausset, A. Danguy and F. Ectors 1972a Immunofluorescent studies on prolactin and the pituitary. In: Prolactin and Carcinogenesis. A. R. Boyns and K. Griffiths, eds. Proc. 4th Tenovus Workshop, Cardiff, Wales, pp. 128-136.

Pasteels, J. L., P. Gausset, A. Danguy, F. Ectors, C. S. Nicoll and P. Varavudha 1972b Morphology of the lactotropes and somatotropes of man and rhesus monkeys. J. Clin. Endocr. Metab., 34: 959-967.

Pasteels, J. L., P. Gausset, F. Ectors, A. Danguy, C. Robyn, M. L'Hermite and M. Dujardin 1972c Histological immunofluorescent and electronmicroscopic identification of prolactin-producing cells in the human pituitary. Proc. 4th Intern. Cong. Endocr., Washington, D. C., Excerpta Med. Found., Internat. Congr. Ser. No. 273, pp. 616-621.

Petrali, J. P., D. M. Hinton, G. C. Moriarty and L. A. Sternberger 1974 The unlabeled antibody enzyme method of immunocytochemistry. Quantitative comparison of sensitivities with and without peroxidase-antiperoxidase complex. J. Histochem. Cytochem., 22: 782-801.

Phifer, R. F., A. R. Midgley and S. S. Spicer 1973 Immunohistologic and histologic evi. dence that follicle-stimulating hormone and luteinizing hormone are present in the same cell type in the human pars distalis. J. Clin. Endocr. Metab., 36: 125-141.

Phifer, R. F., and S. S. Spicer 1973 Immunohis tochemical and histologic demonstration of thyrotropic cells of the human adenohypophysis. J. Clin. Endocr. Metab., 36: 1210-1221.

Pierce, J. G., T.-H. Liao, S. M. Howard, B. Shome and J. S. Cornell 1971 Studies on the structure of thyrotropin: its relationship to luteinizing hormone. Rec. Progr. Horm. Res., 27: 162-212.

Siler-Khodr, R. M., L. L. Morgenstern and F. C Greenwood 1974 Hormone synthesis and release from human fetal adenohypophysis in vitro. J. Clin. Endocr. Metab., 39: 891-905.

Sternberger, L. A., P. H. Hardy, Jr., J. J. Cuculis and H. G. Meyer 1970 The unlabeled antibody enzyme method of immunohistochemistry. Preparation and properties of soluble antigenantibody complex (horseradish peroxidase-antihorseradish peroxidase) and its use in identifica tion of spirochetes. J. Histochem. Cytochem., $18: 315-333$.

Zimmerman, E. A., R. Defendini and A. G. Frantz 1974 Prolactin and growth hormone in pa tients with pituitary adenomas: a correlative study of hormone in tumor and plasma by immunoperoxidase technique and radioimmunoassay. J. Clin. Endocr. Metab,, 38: 577-585. 


\section{PLATES}


PLATE 1

EXAMINATION OF FIGURES

Figures $2-5$ are of sections labeled immunocytochemically with anti-h Prl. $\times 250$

2 Posterolateral zone of the pars distalis of a 6-week old male child, illustrating mammotropes I. Enclosed by the interrupted line is a parenchymal cell cord with many mammotropes I (arrow) aggregated centrally.

3 Anteromedian zone of the pars distalis shown in figure 2. Mammotropes II (arrow) are numerous. Their perikarya are larger than those of mammotropes I of figure 2 and have shorter or no cytoplasmic processes.

4 Posterolateral zone of the pars distalis from a 9-year-old male. The interrupted line encloses a cell cord and the central location of mammotropes I (arrow) is illustrated.

5 Anteromedian zone of the pars distalis shown in figure 4 depicts the larger mammotropes II (arrow). 


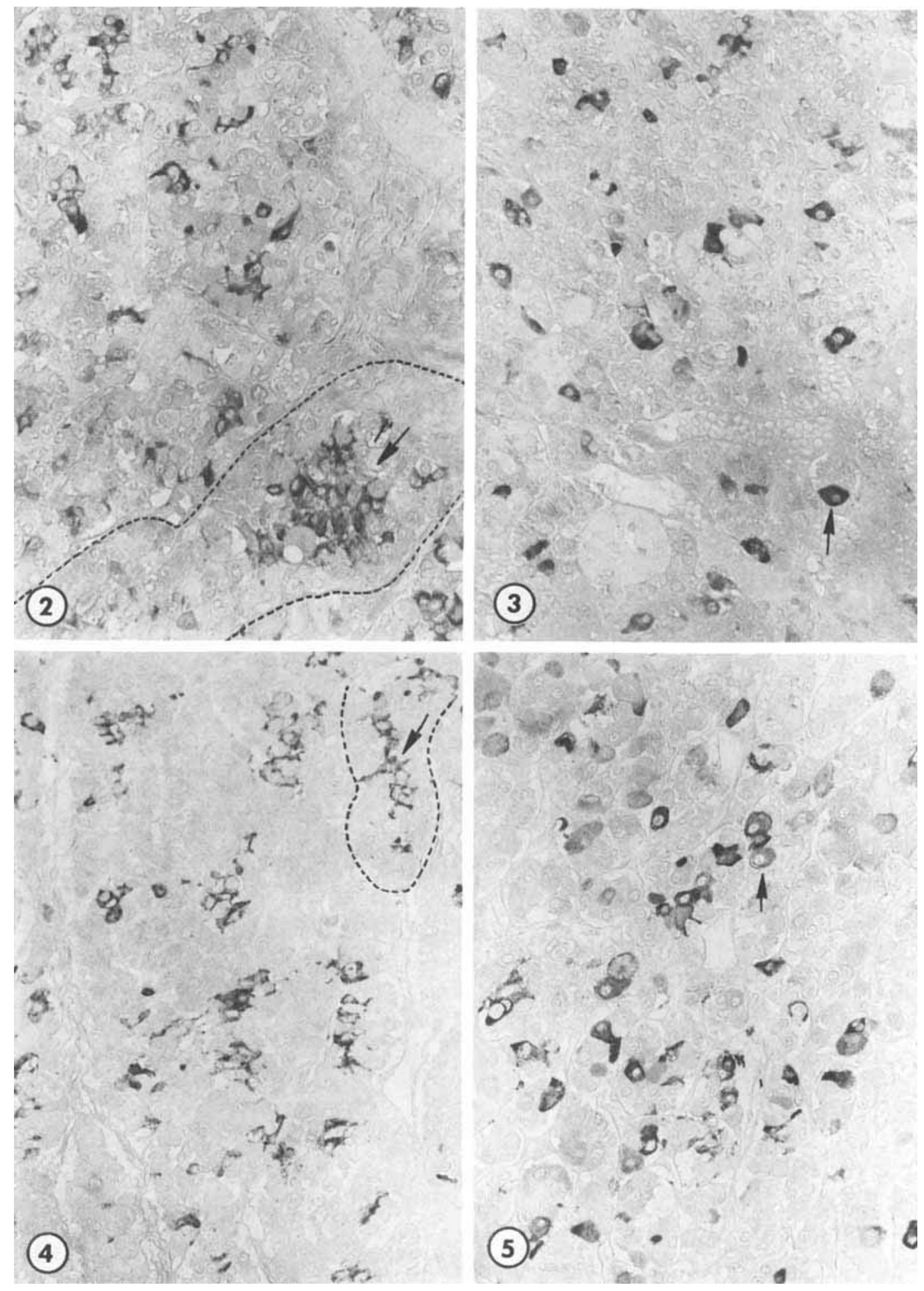


PLATE 2

EXPLANATION OF FIGURES

Figures $6-8$ are of sections labeled immunocytochemically with antihPrl. Figure 9 was labeled with anti-h GH. $\times 250$.

6 Posterolateral zone of the pars distalis of a 36-year-old male, illustrating mammotropes I.

7 Posterolateral zone of the pars distalis of a 36-year-old female. Many of the perikarya of mammotropes are more rounded than those in the male hypophysis of figure 6.

8 Posterolateral zone of the pars distalis from a 76-year-old female. Several poorly labeled small mammotropes are indicated (arrows). Intensity of labeling and size are much reduced as compared with mammotropes of a 36-y ear-old woman (fig. 7).

9 A section close to that illustrated in figure 6 from the posterolateral zone of the pars distalis from a 36-year-old male, showing somatotropes. Evident are marked differences between somatotropes and mammotropes $I$ in shape, size, number and location within the cell cords. Some of the unlabeled cells in the center of the indicated cell cord (interrupted line) are probably mammotropes I. 

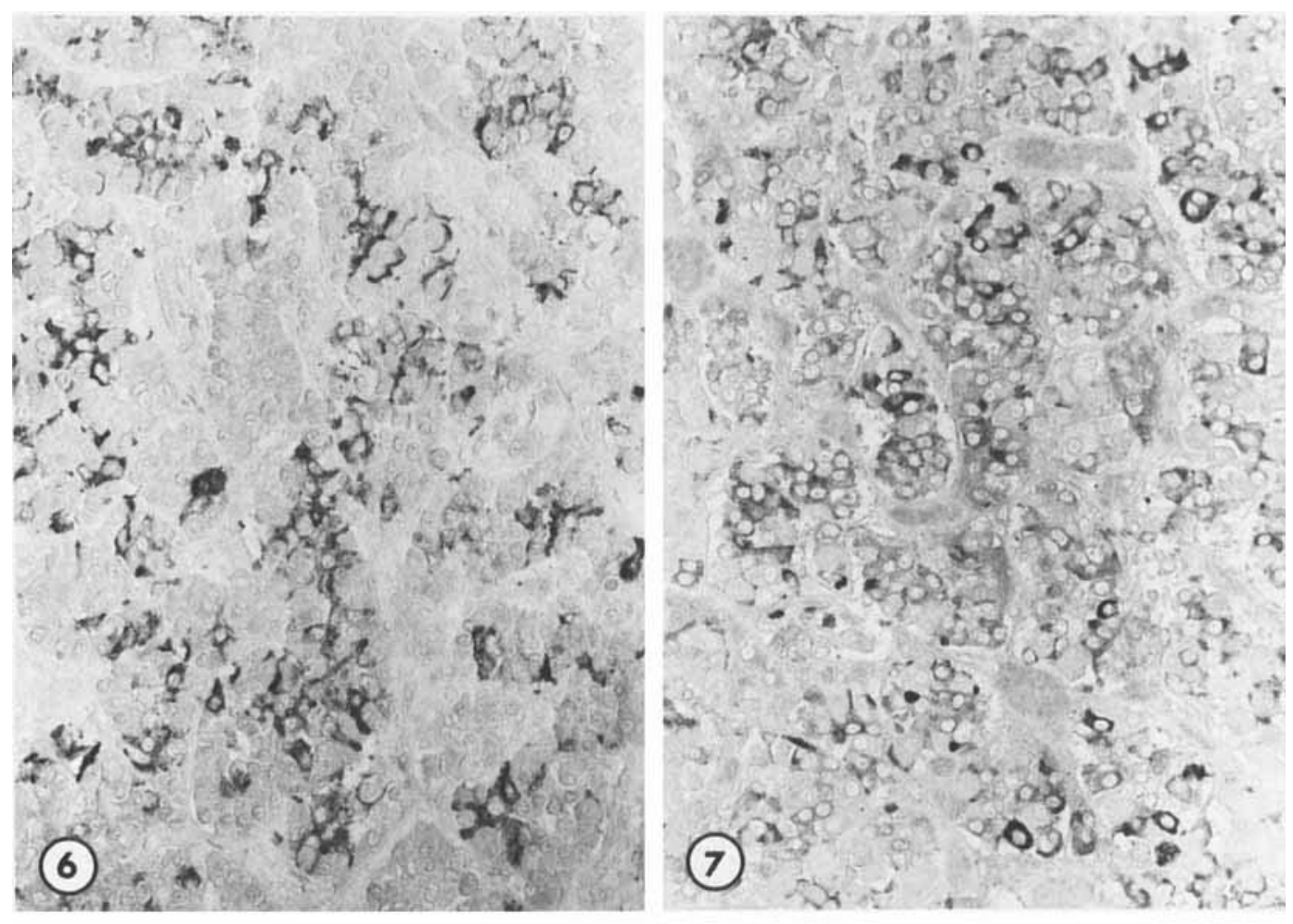

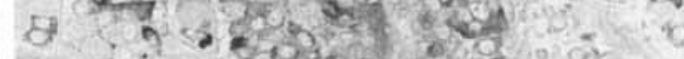

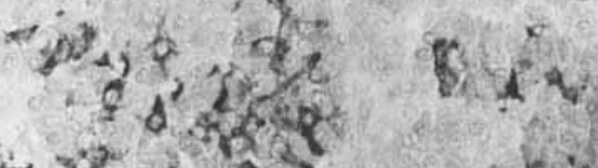
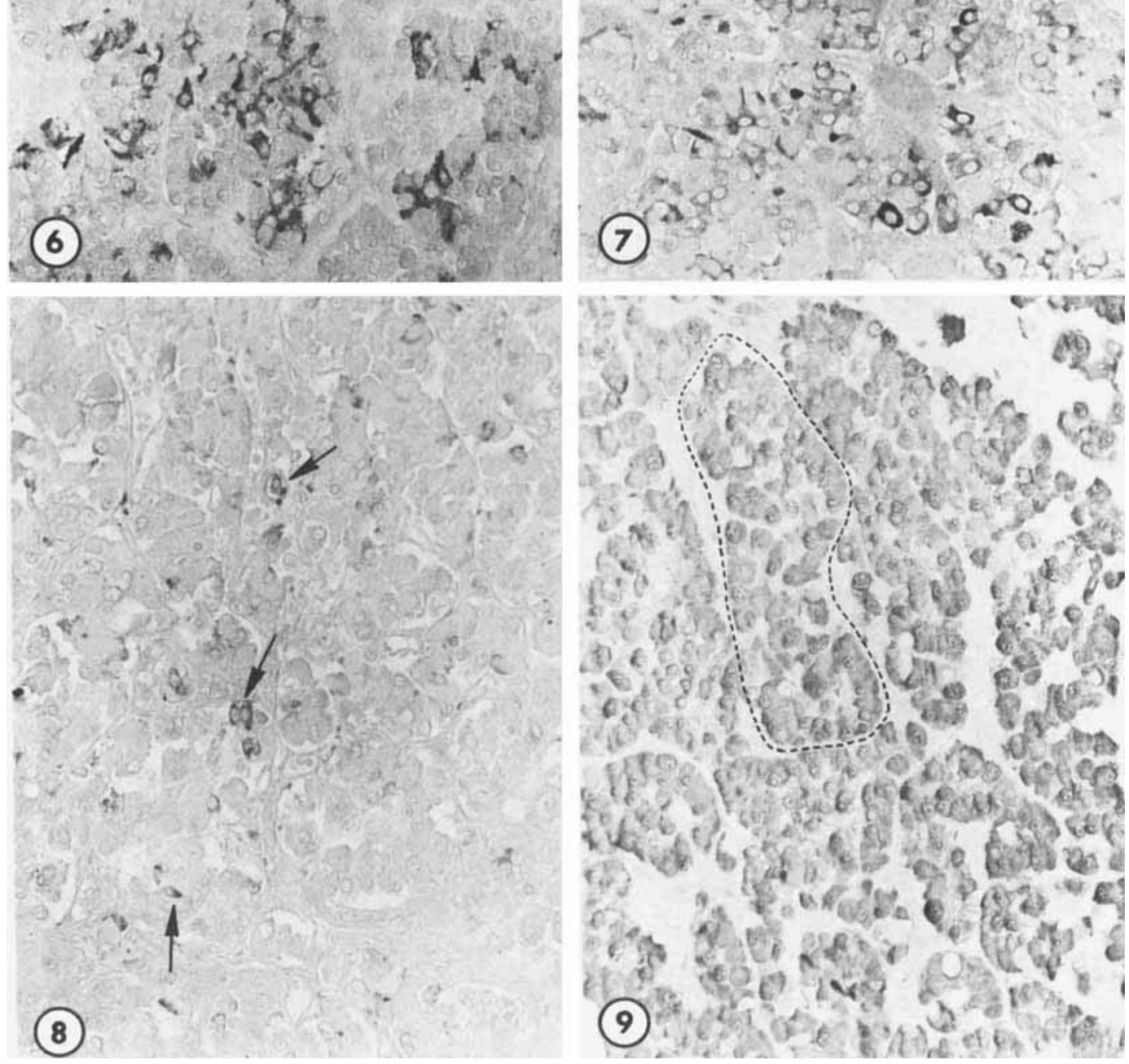

पर 1) ine No

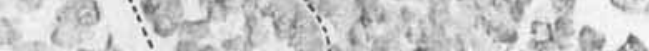

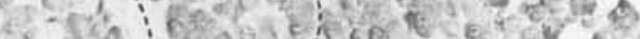

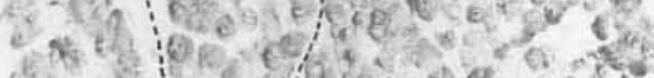

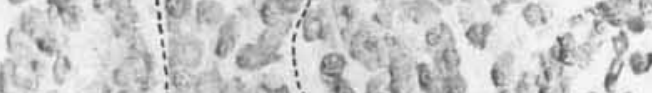

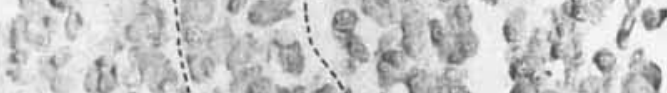

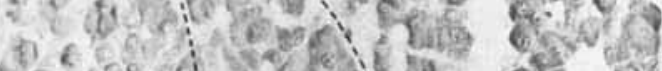

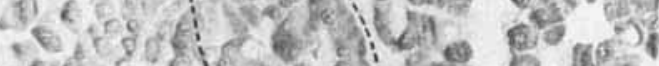
60 g

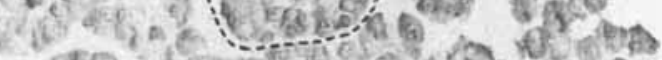

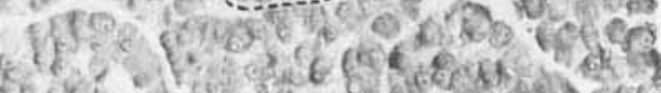

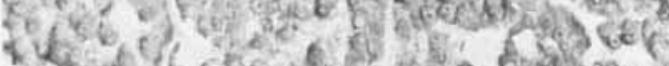
c.

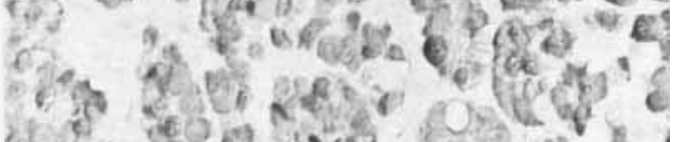

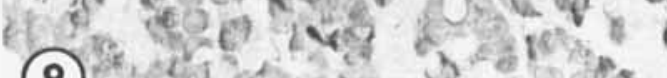
(9) 20 b 
PLATE 3

EXPLANATION OF FIGURES

10,11 Figures 10 and 11 are adjacent sections from the pars distalis of a 36-year-old male, labeled immunocy tochemically with anti-hPrl and anti-h TSH及 preabsorbed with hCG, respectively. The area illustrated is transitional between the posterolateral and anteromedian zones. A cluster of cells is outlined that contains $\mathrm{mam}$. motropes (fig. 10) but no thyrotropes (fig. 11). Identical mammotropes (M) and thy rotropes $(\mathrm{T})$ are identified in both sections to show that they are different cell types. C, capillary. $\times 250$.

12 Anteromedian zone of a 36-year-old male. The section was doubly labeled with anti-hPrl and anti-hCG to show that mammotropes and LH-gonadotropes are different cells. The mammotropes $(M)$ were labeled with DAB and appeared gold; the LH-gonadotropes were labeled with 4-Cl-1-naphthol and were blue. In this region, although variable in size, the gonadotropes were generally smaller and more ovoid than the mammotropes. LG, LH-gonadotrope. $\times 480$.

13 Posterolateral zone of the pars distalis from a 36-year-old male doubly labeled with anti-hPrl and anti-h TSH $\beta$ preabsorbed with hCG to show that mammotropes I and thyrotropes are different cell types. Mammotropes I (M), labeled with DAB, were gold, and the thyrotrope (T) labeled with 4-Cl-1-naph thol was blue. Bulbous terminations (B) of the cytoplasmic processes of the mammotropes appear at the periphery of a cell cord. Note the differences in size, shape and location of the two cell types within the cell cords. $\times 480$. 

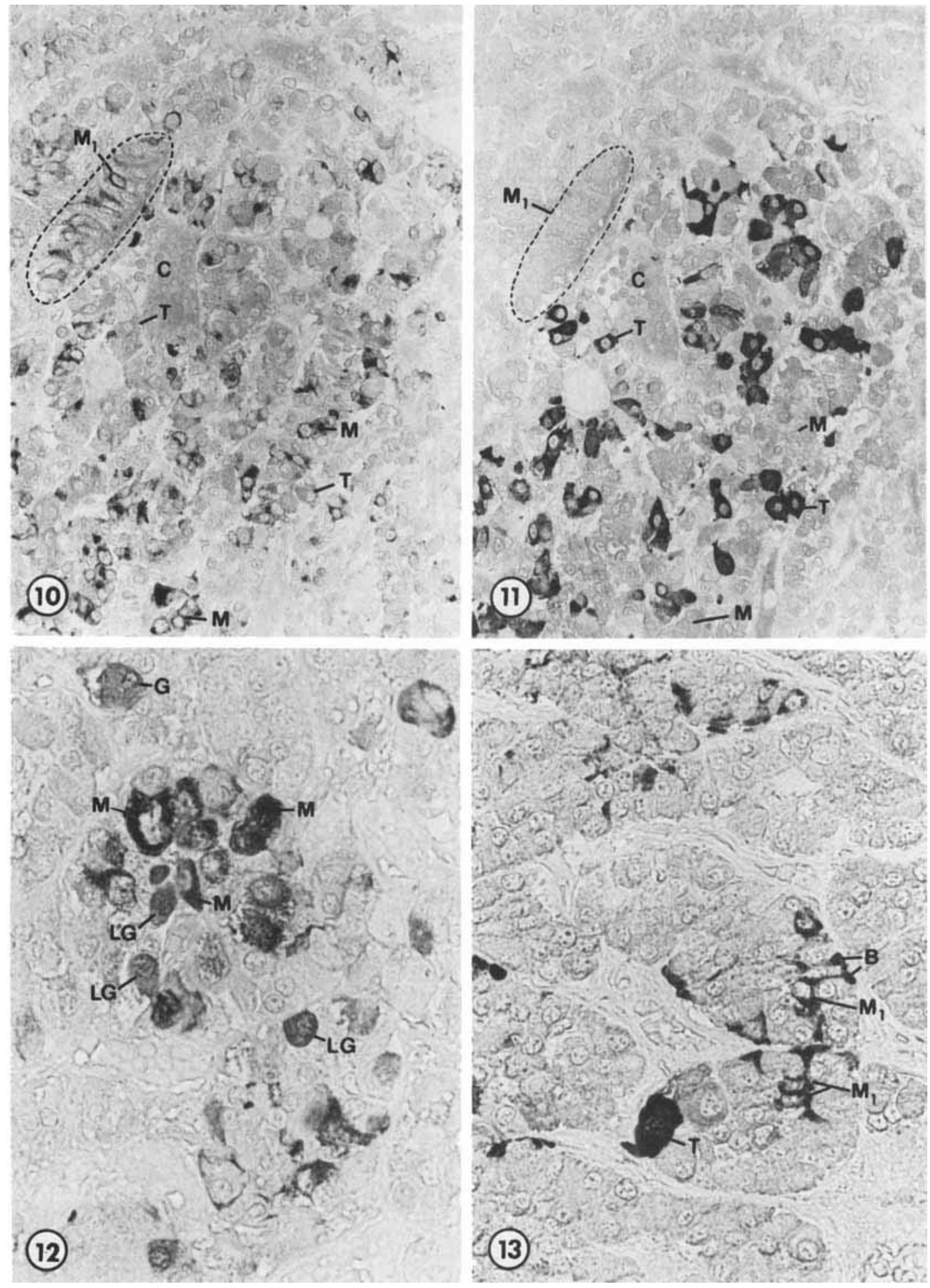
PLATE 4

EXPLANATION OF FIGURES

14 Anteromedian zone of the pars distalis from a 36-year-old male doubly labeled immunocytochemically with anti-hPrl (DAB) and with anti-hGH (4-Cl-1-naphthol). The large mammotropes II (M) were gold and the smaller ovoid somatotropes (S) were blue. $\times 480$.

15 Posterolateral zone of the pars distalis from a 36-year-old male, doubly labeled immunocytochemically with anti-hPrl (DAB) and anti-pB 17-39-corticotropin (4-Cl-1-naphthol). The mammotropes I (M) were gold and the corticotropes (C) blue, $\times 480$.

16,17 Figures 16 and 17 are consecutive sections from the hypophysis (anteromedian zone) of a 36-year-old male, immunocytochemically labeled with anti-hGH (fig. 16) and anti-hPrl (fig. 17) to show that mammotropes (M) and somatotropes (S) are different cells. Identical mammotropes and somatotropes are indicated in the two photographs. C, capillary. $\times 400$. 

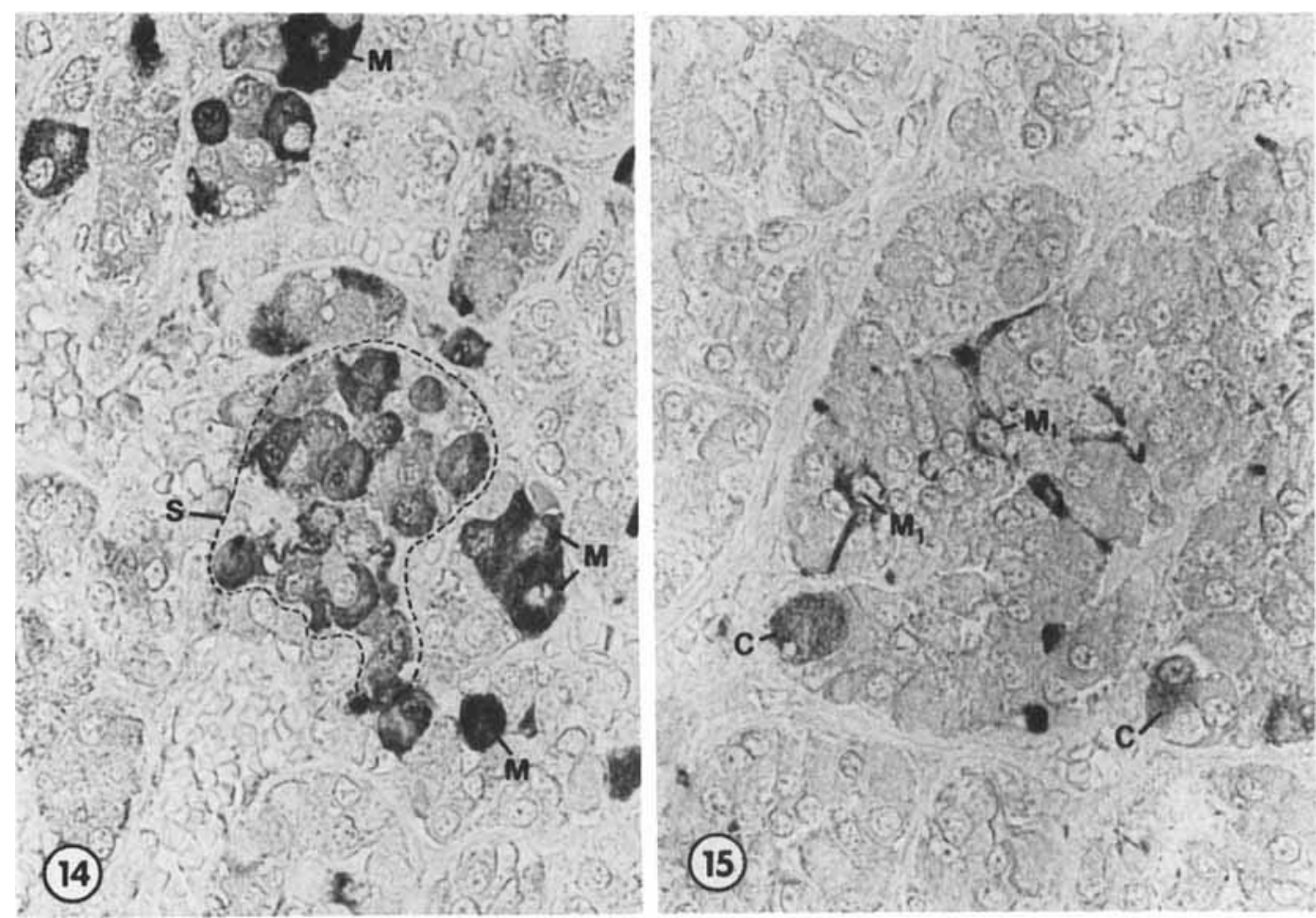

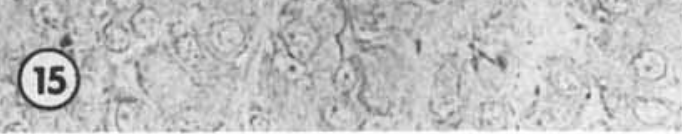
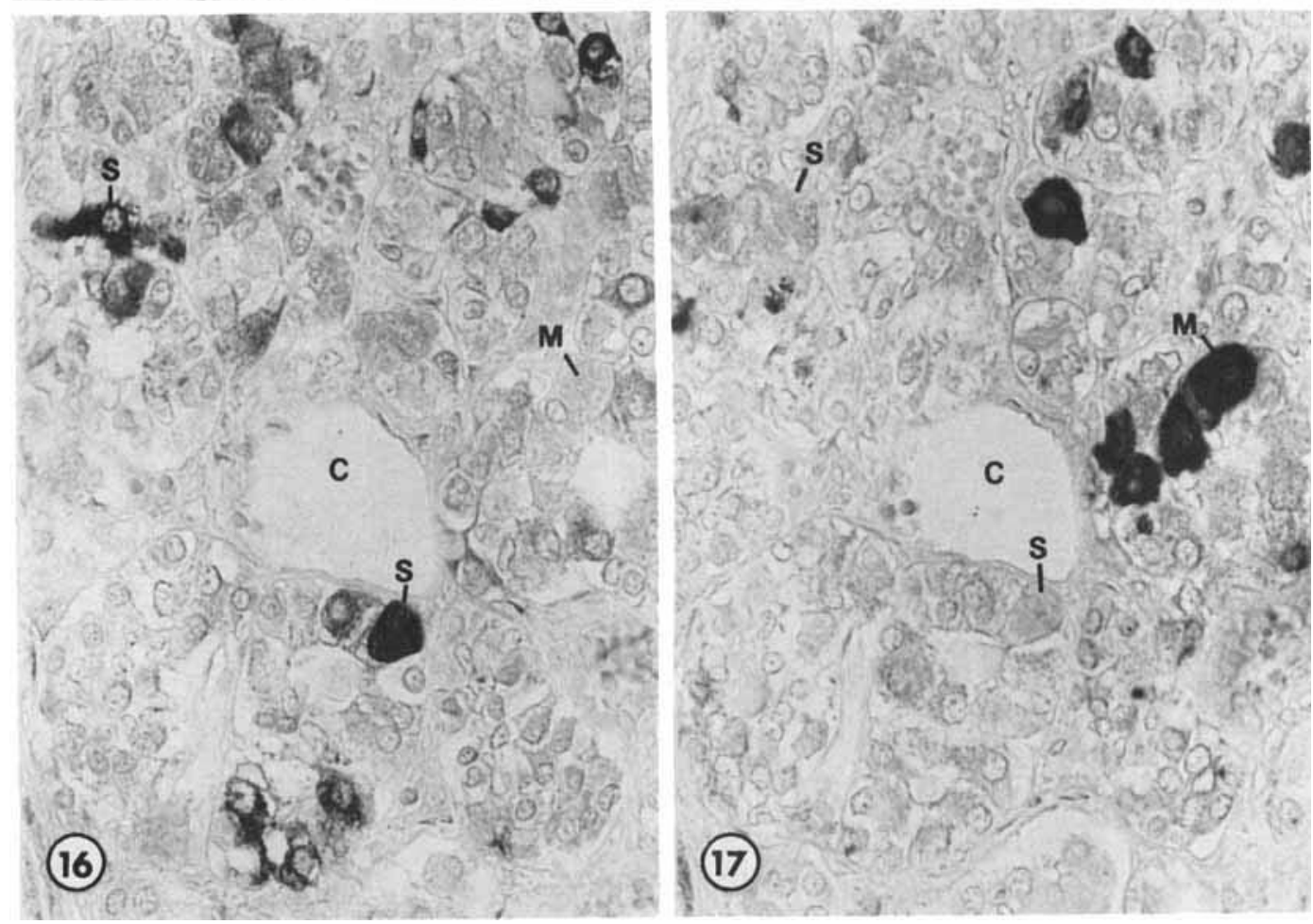
PLATE 5

EXPLANATION OF FIGURES

18 Cross-section of cell cord from the posterolateral zone of a 36 year-old male, labeled immunocytochemically with anti-hPrl to illustrate the typical central location of the perikaryon (arrow) of mammotrope I, in addition to the long cytoplasmic processes with their peripheral bulbous terminations $(B) . \times 480$.

19-21 Figures 19-21 are of neighboring sections of the same area from the pars distalis of a 26-year-old pregnant woman. The sections were labeled immunocytochemically with anti-rPrl, anti-oPrl and antihPrl, respectively, each antiserum being applied for 30 minutes. The same type of cell appears to be demonstrated in the three instances. $\times 350$.

22-25 Figures 22-25 are from the pars distalis of a 26-year-old pregnant woman. Figures 22 and 23 , as well as 24 and 25 , depict consecutive sections. Figures 22 and 24 were stained with the Brookes' procedure, and figures 23 and 25 were labeled immunocytochemically with anti-hPrl to show the identity of the cells revealed by the two procedures. The cluster of carmoisinophilic cells (encircled) in figure 22 is identical with the labeled mammotropes II of figure 23. Similarly, the carmoisinophilic cell (arrow) of figure 24 is identical with a mammotrope I (arrow) of figure $25 . \times 350$ 

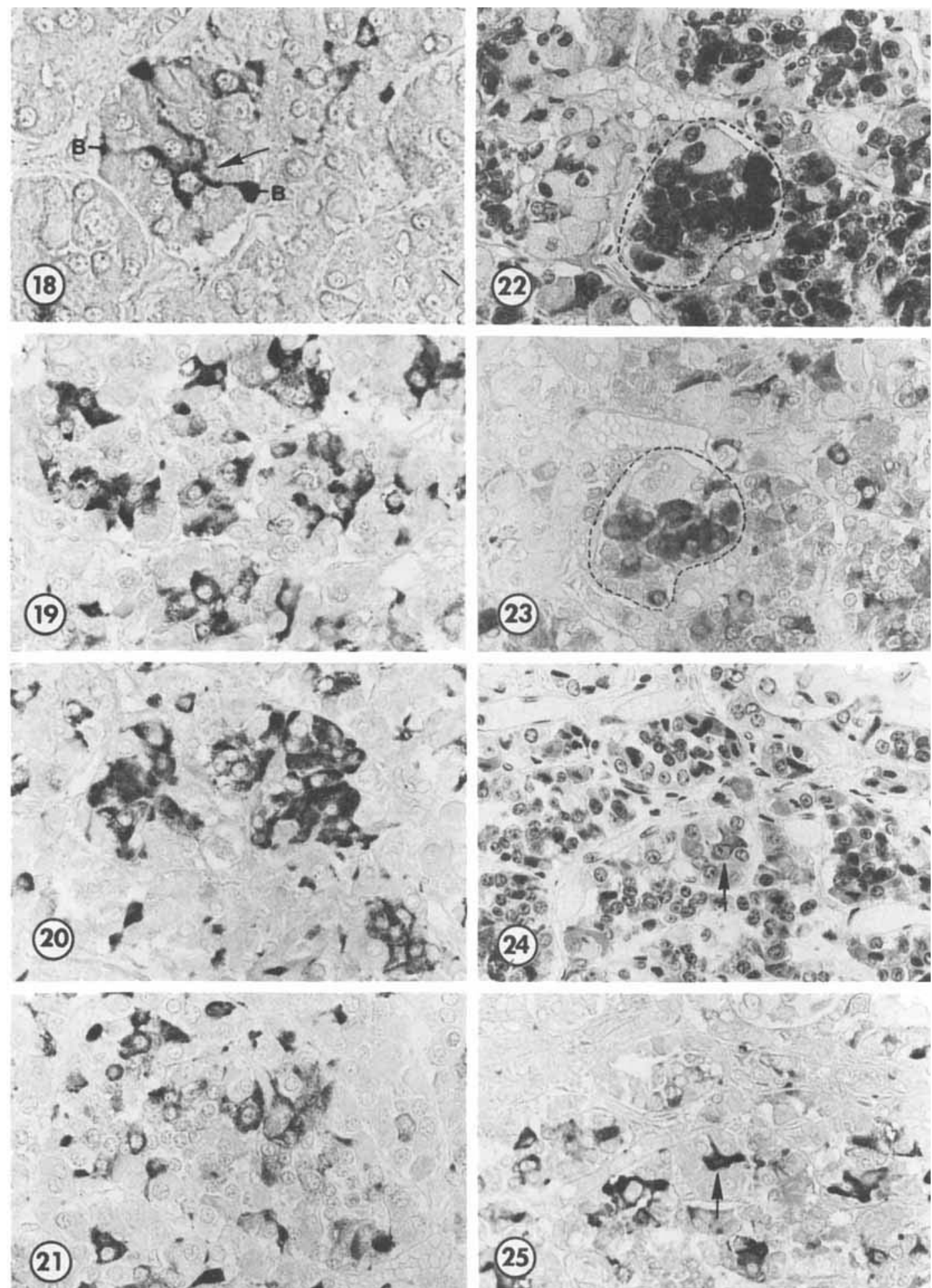

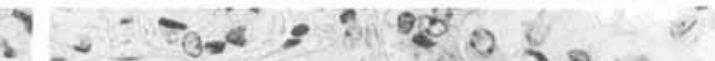
$\because 0$ o

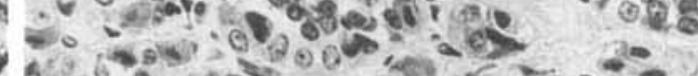
Q6.3.

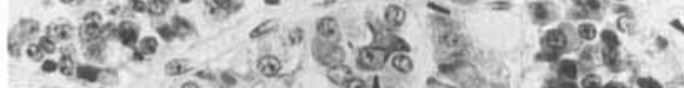

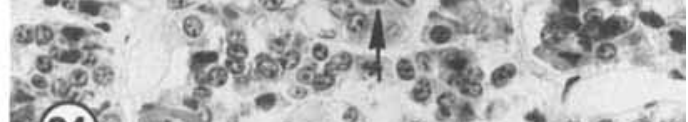
(24) $-70^{2} 0^{\circ}+40 \pi$

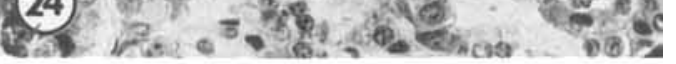


PLATE 6

EXPLANATION OF FIGURES

Illustrated on this plate are sections of fetal hypophyses labeled immunocytochemically with anti-hPrl. Since erthyrocytes appear dark as a result of their endogenous peroxidase, circles are used in figures 26 and 27 to identify the dark dots that are mammotropes. Within the circles may be one or several mammotropes. AM, anteromedian zone; PD, pars distalis; PI, pars intermedia; PN, pars nervosa; PT, pars tuberalis; RC, residual cleft.

26 A portion of transverse section from the hypophysis of a 14-week-old fetus at the level of the trabeculae (Tr). Mammotropes are few and at this level located anterolaterally and in the lateral wing of the pars distalis. Centrally in the anteromedian zone none were found. The anterior pars intermedia was devoid of mammotropes. $\times 38$.

26a High magnification of the mammotrope indic ated $\mathrm{A}$ in figure $26 . \times 1,000$

27 A nearly midsagittal section of the hypophysis of a 15.5-week fetus. Mammotropes are scattered through the pars distalis but are most numerous superiorly near the junction with the pars tuberalis. The upper interrupted line separates pars tuberalis from the median eminence (ME) and infundibular stem (IS). A few mammotropes appear in the pars tuberalis (circle B). The lower interrupted line separates the upper pars nervosa from a dorsal extension (arrows) of the pars intermedia. Although mammotropes are absent from the ventral pars intermedia, they are numerous in the dorsal extension. $\times 38$.

27a High magnification of the mammotrope in circle A of figure 27. $\times 1,000$.

28 A portion of a transverse section of the hypophysis from a 23-week-old fetus at a level inferior to the trabeculae. Mammotropes are numerous throughout the posterolateral (PL) and posteromedial zones of the pars distalis but are much fewer in the anteromedian zone (AM). They are still totally absent from the anterior pars intermedia. $\times 31$.

28a A high-magnification view of several mammotropes in figure 28. The cells are much larger than in the younger fetuses and appear to have larger secretory granules in their cytoplasm. $\times 1,000$. 

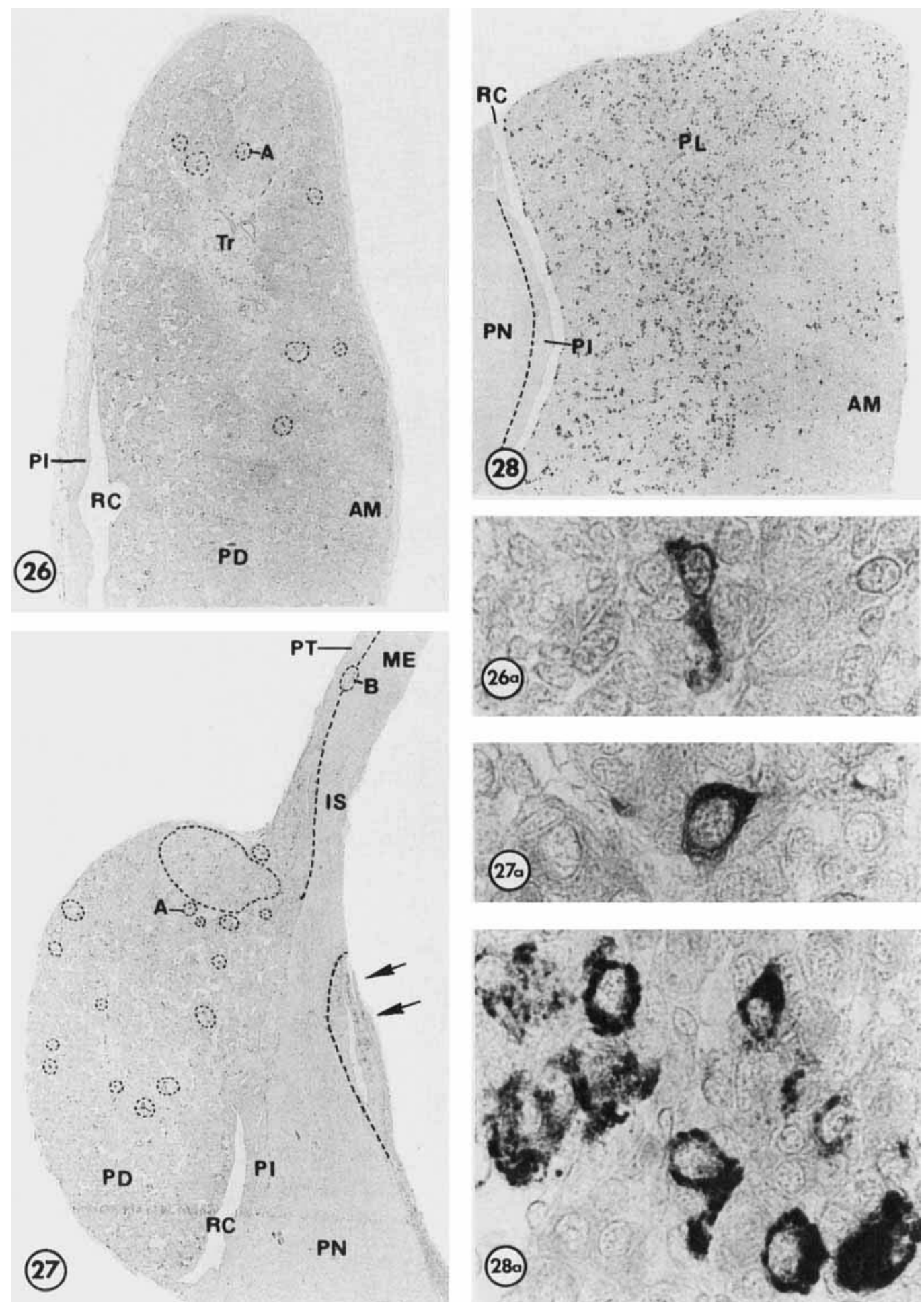